\title{
Opioids Induce Convulsions and Wet Dog Shakes in Rats: Mediation by Hippocampal Mu, But Not Delta or Kappa Opioid Receptors
}

\author{
Paul H. K. Lee, Johnny Obie, and Jau-Shyong Hong \\ Neuropharmacology Section, Laboratory of Molecular and Integrative Neuroscience, National Institute of Environmental \\ Health Sciences, National Institutes of Health, Research Triangle Park, North Carolina 27709
}

\begin{abstract}
The opioid receptor subtypes and brain regions involved in eliciting convulsions and wet dog shakes (WDS) were studied by testing different oplold receptor selective agonists in unanesthetized rats. Selective $\mathrm{mu}$ agonists, [NMe-Phe ${ }^{3}-\mathrm{D}-$ Pro $\left.^{4}\right]$-morphiceptin (PL017) and [D-Ala ${ }^{2}-\mathrm{N}$-methyl-Phe ${ }^{3}-$ Gly ${ }^{5}$-oll-enkephalin, induced convulsions and WDS when unilaterally injected into the ventral hippocampus. [D-Ala ${ }^{2}, \mathrm{D}-$ Leu $^{5}$ ]-enkephalin (DADLE), a mixed mu and delta agonist, also elicited such behavioral changes, but its effect was less potent than the selective mu agonists. DADLE-induced WDS were dose dependent, and both convulsions and WDS were antagonized by the irreversible $\mathrm{mu}$ receptor antagonist, $\beta$-funaltrexamine, but not by the selective delta receptor antagonist, ICl-174,864. Treatment with the selective delta agonist [D-Pen ${ }^{2,5}$ ]-enkephalin or the selective kappa agonists

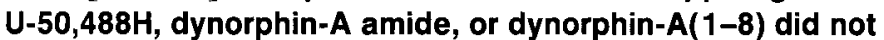
produce convulsions or WDS. The injection of a high dose of PL017 intraventricularly or into other brain regions such as the dorsal hippocampus, frontal cortex, striatum, and amygdala did not produce convulsions or WDS, therefore suggesting the ventral hippocampus is an important site for the expression of opioid-induced convulsions and WDS. These results suggest that opioid-induced convulsions and WDS are mediated exclusively by mu but not delta or kappa opioid receptors in the ventral hippocampus.
\end{abstract}

Intracerebroventricular (icv) administration of morphine to rats has been shown to produce electroencephalographic (EEG) seizures (Urca et al., 1977; Henriksen et al., 1978). Intracerebral or icv injections of endogenous opioid peptides such as $\beta$-endorphin, Met-enkephalin, or Leu-enkephalin also elicit epileptiform spiking at limbic and neocortical areas (Frenk et al., 1978; Henriksen et al., 1978; Snead and Bearden, 1980). The epileptiform discharges produced by opioid peptides are often accompanied by behavioral manifestation of nonconvulsive activities such as myoclonic twitches, stereotypies, and wet dog shakes (WDS) (Frenk, 1983). WDS, a paroxysmal shaking of the head, neck, and trunk, are characteristic behavior observed in morphine-dependent rats after abrupt cessation of morphine administration or after the administration of naloxone (Martin, 1967).

\footnotetext{
Received Apr. 19, 1988; revised July 5, 1988; accepted July 7, 1988.

We wish to thank Miss Malissa Anderson and Mr. Jeffrey Lin for excellent assistance, and Mrs. Tracy Stallings for typing the manuscript.

Correspondence should be addressed to Dr. Jau-Shyong Hong, Laboratory of Molecular and Integrative Neuroscience, National Institute of Environmental Health Sciences, P.O. Box 12233, Research Triangle Park, NC 27709.

0270-6474/89/020692-06\$02.00/0
}

Precipitation of WDS by icv injection of opioid peptides, such as $\beta$-endorphin and enkephalins, always accompany the onset of epileptiform discharges (Frenk et al., 1978; Henriksen et al., 1978), therefore suggesting that there may be an association between electrical seizure activities and WDS induced by opioid peptides.

Several lines of evidence suggest that opiate-induced EEG seizures are mediated by specific opioid receptors. First, these EEG seizures occur in a dose-related manner and can be antagonized by opiate antagonists such as naloxone and $\beta$-funaltrexamine (Tortella et al., 1987). Second, tolerance to the EEG scizures produced by opioid peptides develops after repeated icv or intracerebral injections (Tortella et al., 1979; Cain and Corcoran, 1985). This evidence also suggests that the endogenous opioid peptides may play a role in the expression of epileptiform activity.

The hippocampus has been suggested to be an important site for the manifestation of seizure activities. The most intensive and long-lasting epileptic discharges after icv administration of opioid peptides are observed in hippocampus (Haffmans et al., 1983). The uptake of 2-deoxyglucose (2-DG) is increased in the hippocampus after systemic administration of kainic acid (Lothman and Collins, 1981) or icv administration of opioid peptides (Haffmans et al., 1984). Generalized convulsions can be chemically kindled by repeated administration of $\left[\mathrm{Met}^{5}\right]$-enkephalin (ME) or $\beta$-endorphin into the hippocampus (Cain and Corcoran, $1984,1985)$. Furthermore, we have recently demonstrated that a single unilateral injection of specific mu receptor agonist [NMcPhe $^{3}$-D-Pro ${ }^{4}$-morphiceptin (PL017; Chang et al., 1983; Blanchard et al., 1987) into the ventral hippocampus resulted in a dose-related increase in the frequency of convulsions and WDS (Lee et al., 1988). The present study further investigates the role of hippocampal opioid receptor subtypes-mu, delta and kappa- on the expression of convulsions and WDS. In addition, brain regions other than ventral hippocampus are also tested to understand which regions may be involved in opioid-induced convulsions.

\section{Materials and Methods}

Animals. Male Fischer-344 rats (Charles River, Wilmington, MA) weighing $280-320 \mathrm{gm}$ were used. The animals were housed 4 per cage in a room maintained at $21 \pm 2^{\circ} \mathrm{C}$ and $50 \pm 10 \%$ humidity with a standard 12/12 hr light/dark cycle. Food and water were available ad libitum.

Cannula implantation. Five days before experimentation, rats were anesthetized with ketamine $\mathrm{HCl}(100 \mathrm{mg} / \mathrm{kg}$, i.p. $)$, and a stainless steel guide cannula (22 gauge; Plastic Products, Co., Roanoke, VA) was stereotaxically implanted in each rat such that an injection cannula (stainless steel, 28 gauge; Plastic Products Co.) could be aimed at one of the 
following brain regions according to the rat brain atlas of Paxinos and Watson (1982): ventral hippocampus $5.8 \mathrm{~mm}$ posterior $(\mathrm{P}) ; 5.0 \mathrm{~mm}$ lateral $(\mathrm{L})$ and $7.5 \mathrm{~mm}$ ventral $(\mathrm{V})$, dorsal hippocampus $\mathrm{CA}_{3} / \mathrm{CA}_{2}$ region (P: $3.8 \mathrm{~mm}$; L: $3.5 \mathrm{~mm}$; V: $3.5 \mathrm{~mm}$ ), CA region $(\mathrm{P}: 3.8 \mathrm{~mm}$; L: 2.0 $\mathrm{mm} ; \mathrm{V}: 2.5 \mathrm{~mm}$ ), amygdala (P:2.8 mm; L: $5.0 \mathrm{~mm} ; \mathrm{V}: 8.0 \mathrm{~mm})$, striatum (anterior: $1.2 \mathrm{~mm}$; L: $2.5 \mathrm{~mm} ; \mathrm{V}: 5.0 \mathrm{~mm}$ ), frontal cortex (anterior: 1.2 $\mathrm{mm}$; L: $3.0 \mathrm{~mm}$; V: $2.0 \mathrm{~mm}$ ) and icv (P: $0.8 \mathrm{~mm}$; $: 1.5 \mathrm{~mm} ; \mathrm{V}: 3.5$ $\mathrm{mm}$ ). The incisor bars were set at $3.3 \mathrm{~mm}$ below the interaural line, and all measurements originated at the bregma. The guide cannula was permanently anchored to the skull using miniature screws and dental acrylic, and was sealed with a dummy injection cannula (stainless steel, 28 gaugc; Plastic Products Co.) until the time of injection.

Behavioral study. On the day of the experiment, animals were gently held by hand, and the dummy injection cannula was replaced with an injection cannula, which was connected by PE-20 tubing to a $10 \mu \mathrm{l}$ Hamilton syringe on a Sage infusion pump. All infusions were delivered in a volume of $0.5 \mu \mathrm{l}$ at a rate of $0.008 \mu \mathrm{l} / \mathrm{sec}$ to brain regions mentioned except for icv administration, for which $5 \mu \mathrm{l}$ was delivered at a rate of $0.033 \mu \mathrm{l} / \mathrm{sec}$. The following drugs were used in this study: PL017, [DAla ${ }^{2}-N$-methyl-Phe ${ }^{4}$-Gly ${ }^{5}$-ol]-enkephalin (DAGO), [D-Ala ${ }^{2}, \mathrm{D}-\mathrm{Leu}^{5}$ ]-enkephalin (DADLE), [D-Pen ${ }^{2,5}$-enkephalin (DPDPE), dynorphin-A(1-8) (DYN), and dynorphin-A amide (DYN-A amide) were purchased from Peninsula Laboratories, Inc. (Belmont, CA). Trans-3,4-dichloro- $N$ methyl- $N(2-(1-$ pyrrolidinyl)-cyclohexyl)-benzeneacetamide methanesulfonate hydrate $(\mathrm{U}-50,488 \mathrm{H})$ was obtained from the Upjohn Co. (Kalamazoo, MI). $\beta$-Funaltrexamine ( $\beta$-FNA) and ICI-174,864 wcre purchased from Research Biochemicals Inc. (Wayland, MA) and Cambridge Research Biochemicals Ltd. (Valley Stream, NY), respectively. All drugs were dissolved in artificial cerebrospinal fluid (ACSF; Lee et al., 1988) to the dosage mentioned in the text. Each animal was injected only once except for the antagonist study, where $\beta$-FNA $(2 \mathrm{nmol})$ or ICI-174,864 (1.5 nmol) was injected $24 \mathrm{hr}$ and $10 \mathrm{~min}$, respectively, before DADLE administration. Control animals were injected with 0.5 $\mu \mathrm{l}$ of ACSF. After drug administration animals were placed in individual observation chambers $(40 \times 24 \times 15 \mathrm{~cm})$. The frequency of WDS and convulsions were recorded throughout a $1 \mathrm{hr}$ period by observers with no knowledge of the treatment given to the rats. At completion of the observation, the animal was decapitated with the whole brain immediately dissected and frozen on dry ice. Tissue sections of frozen brain were mounted on slides and stained with $1 \%$ thionin to verify the injection site.

Statistics. Results were analyzed statistically using an analysis of variance, followed by comparisons between groups using Fisher's leastsignificance difference test. Differences were considered significant at the level $p<0.05$.

\section{Results}

\section{Regional specificity}

A single unilateral infusion of PLO17 (18.7 nmol) to the ventral hippocampus induced convulsions and numerous WDS in all of the rats treated, the frequency of these behaviors is shown in Figure 1. However, no convulsions or augmented WDS were observed when the same dose of PL017 was infused unilaterally into the left lateral ventricle, amygdala, striatum, frontal cortex, or dorsal hippocampus (Figs. 1, 2). For the dorsal hippocampus, infusion of $\mathrm{PLO} 17$ to $\mathrm{CA}_{1}$ or $\mathrm{CA}_{2} / \mathrm{CA}_{3}$ region produced 6 and $5 \mathrm{WDS} / \mathrm{hr}$, respectively, and there was no behavioral difference observed between the 2 sites of administration; therefore, these results were combined in Figure 1. Similarly, no manifestation of behavioral seizure activity was observed after the administration of PLO1 7 into the frontal cortex. In the icv infused rats, a few WDS were observed before the animals assumed and maintained a fixed posture, which occurred 1-3 min after the administration of PL017 and lasted for 30-50 min. Striatal administration of PL017 also induced immobilization, which started at about $3 \mathrm{~min}$ after the infusion, and the effect lasted longer than $60 \mathrm{~min}$. No WDS or other behavioral seizure activity was observed in striatal-treated rats. Administration of PL017 to the left amygdala produced masticatory movement in 8 of 9

\section{REGIONAL SELECTIVITY OF PL017-INDUCED WET DOG SHAKES AND CONVULSIONS}

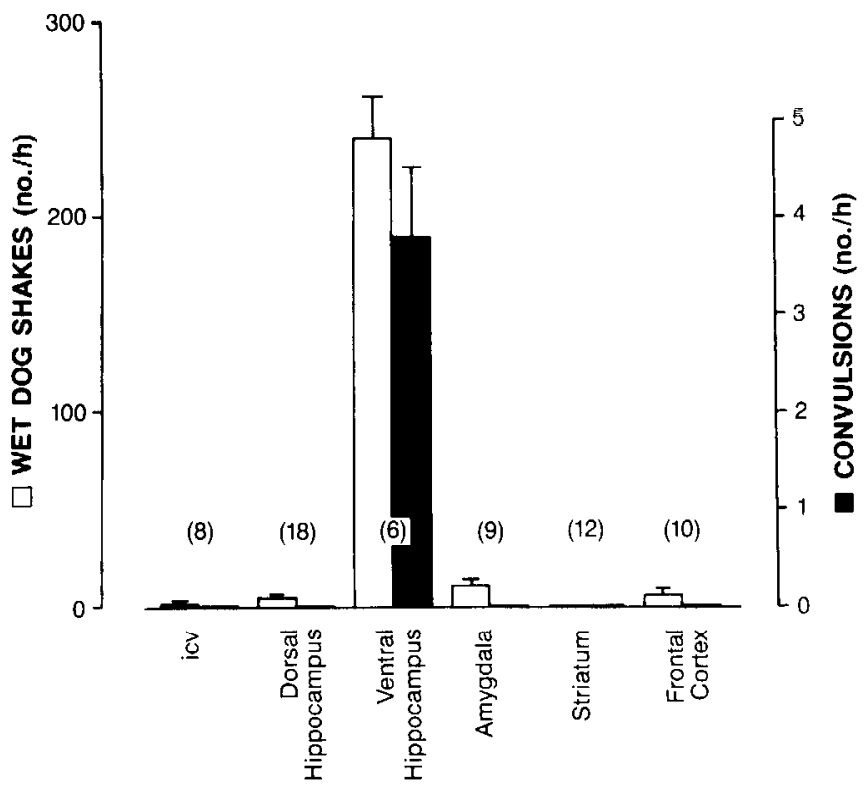

Figure 1. Regional selectivity of PL017-induced WDS and convulsions. Values are expressed as means \pm SEM. The numbers in parentheses represent the number of rats in each group. PL017 $18.7 \mathrm{nmol}$ was infused in a volume of $0.5 \mu \mathrm{l}$ to each brain region except for icv, which was delivered in $5 \mu 1$.

rats, and a few WDS were observed, but no other behavioral seizure activity was observed within the $1 \mathrm{hr}$ observation period.

\section{Receptor specificity}

Besides PL017, a single unilateral injection of DAGO, a selective mu opioid receptor agonist (Handa et al., 1981), or DADLE, a mixed mu-delta receptor agonist (Zajac et al., 1983; James and Goldstein, 1984), to the ventral hippocampus also induced convulsions and numerous WDS (Fig. 3). With similar doses administered (PL017, $9.4 \mathrm{nmol}$; DAGO, $9.7 \mathrm{nmol}$; DADLE, $8.8 \mathrm{nmol}$ ), the number of animals that developed convulsions was higher in PL017- and DAGO-treated groups (PL017, 7/10; DAGO, 5/6; DADLE, 2/8), and these animals also had more convulsions than DADLE-treated rats within the same observation period (Fig. 3). Administration of DPDPE ( $7.7 \mathrm{nmol}$ ), a selective delta agonist (Mosberg et al., 1983), or DYN (10.2 nmol), DYN-A amide (4.7 nmol), and U-50,488H (21.5 nmol), the selective kappa agonist (Von Voightlander et al., 1983; Tang and Collins, 1985), to the ventral hippocampus did not elicit convulsions or augmented WDS (Fig. 3). Moreover, neither one of these opioid compounds produced overt behavioral changes compared with the ACSF controls.

The effects of $\beta$-FNA, an irreversible mu-selective antagonist (Takemori et al., 1981), and ICI-174,864, a selective delta antagonist (Cotton et al., 1984), on DADLE-induced WDS and convulsions are shown in Table 1 . Administration of $\beta$-FNA (2 nmol) to the ventral hippocampus $24 \mathrm{hr}$ prior to DADLE injection completely antagonized ( $p<0.001$, Table 1$)$ DADLEinduced WDS and convulsions. On the other hand, ICI-174,864 $(1.5 \mathrm{nmol})$ injected into the ventral hippocampus $10 \mathrm{~min}$ before DADLE showed no inhibitory effect on DADLE-induced WDS and convulsions. 


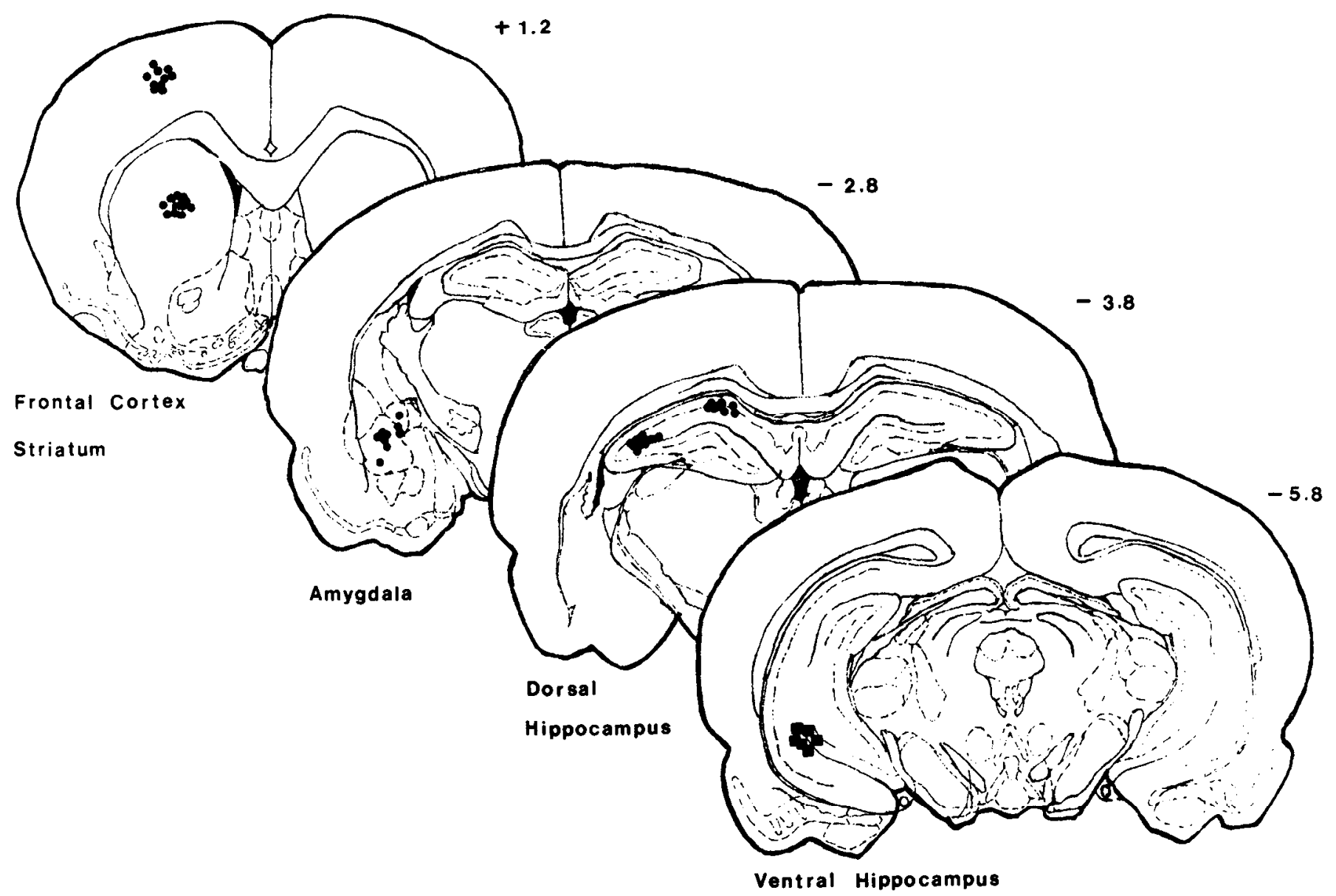

Figure 2. Sites of injection of PL017. Injection resulted in convulsions ( $\square$ ) or had no effect (๑).

\section{Dose dependency}

WDS elicited by infusion of DADLE $(1.8-17.6 \mathrm{nmol})$ to the ventral hippocampus were dose-related, and all except the 1.8 nmol dose were significantly higher $(p<0.05$ for $4.4 \mathrm{nmol} ; p$ $<0.001$ for $8.8 \mathrm{nmol}$ and $17.6 \mathrm{nmol}$; Fig. 4) than the ACSFtreated controls $(12.0+3.1$ shakes $/ \mathrm{hr})$. DADLE-induced convulsions did not show a dose-dependent effect in the range of doses tested (Table 2). Although the highest dose of DADLE $(17.6 \mathrm{nmol})$ appeared to produce more convulsions and an ear- lier onset of the first convulsion, the difference with other doses tested was not statistically significant.

\section{Discussion}

The present study shows that a single injection of the selective $\mathrm{mu}$ opioid receptor agonists PL017 or DAGO into the ventral hippocampus of rats elicited convulsions and WDS. Observation of a dose-related increase in WDS and convulsions after the administration of a mixed mu and delta receptor agonist, DADLE, into the ventral hippocampus implies that delta re-

Table 1. Effects of $\beta$-FNA and ICI-174,864 on DADLE-induced WDS and convulsions

\begin{tabular}{|c|c|c|c|c|c|}
\hline Treatment & $N$ & $\begin{array}{l}\text { WDS } \\
(n / \mathrm{hr})\end{array}$ & $\begin{array}{l}\text { Fraction } \\
\text { responding }\end{array}$ & $\begin{array}{l}\text { Convulsions }{ }^{a} \\
(n / \mathrm{hr})\end{array}$ & $\begin{array}{l}\text { Onset of the first } \\
\text { convulsion } \\
\text { (min) }\end{array}$ \\
\hline $\begin{array}{l}\text { ACSF } \\
\text { (control) } \\
\beta \text {-FNA }\end{array}$ & 18 & $181.4 \pm 14.2$ & $9 / 18$ & $1.3 \pm 0.2$ & $19.9 \pm 4.1$ \\
\hline$(2.0 \mathrm{nmol})$ & 10 & $8.5 \pm 1.7^{h}$ & $0 / 10$ & 0 & - \\
\hline $\begin{array}{r}\text { ICI- } 174,864 \\
(1.5 \mathrm{nmol})\end{array}$ & 11 & $171.4 \pm 26.7$ & $6 / 11$ & $2.5 \pm 0.6$ & $18.8+3.5$ \\
\hline
\end{tabular}

$N$ represents number of rats per group; fraction responding, number of rats per group responding to a single injection of $4.4 \mathrm{nmol}$ DADLE to the left ventral hippocampus with at least one convulsion.

"Values are means \pm SEM of rats that have convulsions.

" $p<0.001$ compared with the control value. 
EFFECTIVENESS OF INTRAHIPPOCAMPAL INJECTION OF DIFFERENT OPIOID RECEPTOR AGONISTS IN ELICITING WET DOG SHAKES AND CONVULSIONS

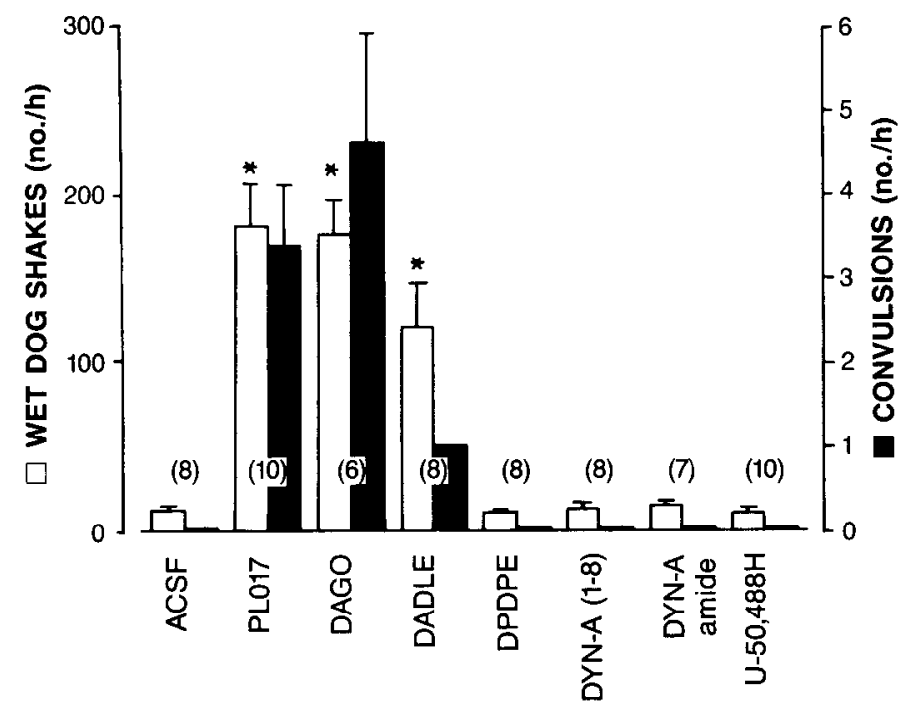

Figure 3. Effects of different opioid receptor agonists in eliciting WDS and convulsions. Values are expressed as means \pm SEM. The numbers in parentheses represent the number of rats in each group. All drugs were infused into the left ventral hippocampus in a volume of $0.5 \mu \mathrm{l}$ in the following concentration: PL017, 9.4 mmol; DAGO, 9.7 nmol; DADLE, $8.8 \mathrm{nmol}$; DPDPE, $7.7 \mathrm{nmol}$; DYN-A(1-8), $10.2 \mathrm{nmol}$; DYN-A amide, $4.7 \mathrm{nmol}$; and U-50,488H, $21.5 \mathrm{nmol}^{*}{ }^{*} p<0.001$ compared with the ACSF control.

ceptors may also be involved in the expression of these behavioral changes. However, WDS and convulsions induced by DADLE could only be antagonized by the irreversible mu-selective antagonist $\beta$-FNA but not by the selective delta receptor antagonist ICI-174,864. These findings strongly suggest that such behavioral changes are mediated by activation of mu receptors rather than by delta receptors in the ventral hippocampus. The fact that neither the selective delta agonist DPDPE nor the selective kappa agonist $\mathrm{U}-50,488 \mathrm{H}$ administered to the ventral hippocampus evoked such behaviors further demonstrates that convulsions and WDS are unlikely to be mediated via delta or kappa receptors. Furthermore, it has been shown that icv administration of U-50,488H does not produce any epileptic discharges or myoclonic contractions (Dzoljic and Poel-Heisterkamp, 1982). The lack of effect of U-50,448H in eliciting convulsions and WDS, and the higher order of potency of PL017 and DAGO compared with that of DADLE (Fig. 3), suggests that these behavioral changes were mediated exclusively by mu but not delta or kappa opioid receptors.

Earlier findings suggest that the EEG seizures produced by opioid peptides may be a consequence of the activation of the delta opioid receptor subtypes (Urca et al., 1977; Frenk, 1983; Haffmans and Dzoljic, 1983) or perhaps multiple opioid receptor-mediated mechanisms may be involved (Snead, 1986). Although the multiplicity of opioid receptor subtypes has been established based on in vivo (Martin et al., 1976; Cowan et al., 1979; Holaday and Tortella, 1984) and in vitro (Lord et al., 1977; Chang and Cuatrecasas, 1979) evidence, it was not until recently that highly selective agonists and antagonists for various opioid receptor subtypes became available. Our findings are in accord with those reported by Tortella et al. $(1984,1987)$, who demonstrated by intraventricular administration of selective ag-

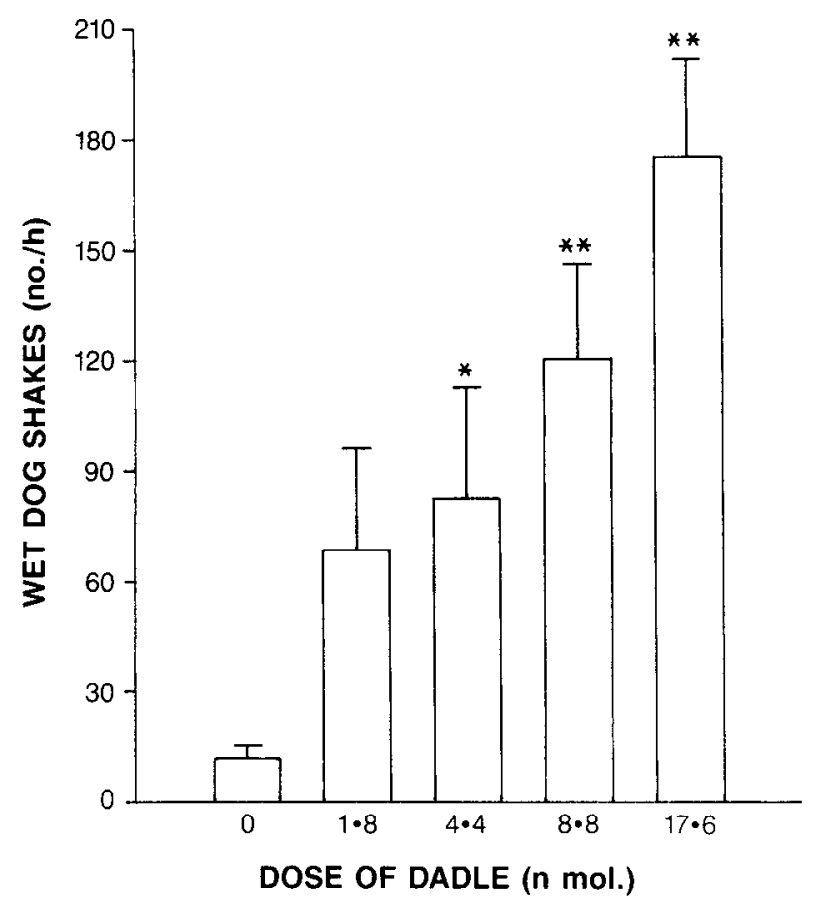

Figure 4. Dose-related effect of DADLE-induced WDS. Values are expressed as means \pm SEM of 8 rats. DADLE was infused into the left ventral hippocampus in a volume of $0.5 \mu \mathrm{l} .{ }^{*} p<0.05$ and ${ }^{* *} p<0.001$ compared with the ACSF control.

onists and antagonists for mu and delta opioid receptors that the EEG seizures evoked were mediated by mu rather than delta opioid receptors. The present study further extends this idea by showing an exclusive role of the ventral hippocampal mu receptors in eliciting convulsions since only injecting selective mu but not delta or kappa receptor agonists into the ventral, but not dorsal, hippocampus produced convulsions in rats. Moreover, convulsions induced by DADLE were inhibited by $\beta$-FNA but not by ICI-174,864.

Injection of PL017 into other brain regions such as the striatum, frontal cortex, amygdala, and dorsal hippocampus or by icv administration did not elicit WDS or convulsions, therefore this clearly indicates that this PL017-induced effect is regionally specific. A number of observations have shown that with repeated injections of $10 \mu \mathrm{g} \beta$-endorphin or Met-enkephalin into either the hippocampus (dorsal or ventral) or amygdala of rats leads to the development of kindled generalized convulsions

Table 2. DADLE-induced convulsions

\begin{tabular}{llll} 
Treatment & $\begin{array}{l}\text { Fraction } \\
\text { responding }\end{array}$ & $\begin{array}{l}\text { Convulsions } \\
(n / \mathrm{hr})\end{array}$ & $\begin{array}{l}\text { Onset of the first } \\
\text { convulsion } \\
(\mathrm{min})\end{array}$ \\
\hline ACSF (control) & $0 / 8$ & 0 & - \\
DADLE & & & \\
$1.8 \mathrm{nmol}$ & $2 / 8$ & 2 & 21.5 \\
$4.4 \mathrm{nmol}$ & $2 / 8$ & 1 & 21.5 \\
$8.8 \mathrm{nmol}$ & $2 / 8$ & 1 & 27.0 \\
$17.6 \mathrm{nmol}$ & $3 / 8$ & $3.3 \pm 1.4$ & $18.3 \pm 3.9$
\end{tabular}

Fraction responding refers to the number of rats per group responding $t o$ a single infusion of DADLE to the left ventral hippocampus with at least one convulsion. Values are means or means \pm SEM of rats that had convulsions. 
(Cain and Corcoran, 1985; Tanaka et al., 1986). We have demonstrated that only a single injection of $1 \mu \mathrm{g}$ PL017 to the ventral hippocampus is needed to evoke convulsions in rats, and this effect is antagonized by $\beta$-FNA (Lee et al., 1987, 1988). Hence, the use of highly selective and potent mu receptor ligands, which probably reduce the activation of other opioid receptors, may contribute to the differences observed in these studies. In the present study no overt behavioral manisfestations of motor seizures was observed after injection of a high dose of PL017 (10 $\mu \mathrm{g}$ ) to the dorsal hippocampus (both $\mathrm{CA}_{3} / \mathrm{CA}_{2}$ and $\mathrm{CA}_{1}$ regions), whereas for the amygdala, only masticatory movement was observed. This regional difference in the effect of PL017 does not result from differences in the mu opioid receptor distribution since it is present in both amygdala and dorsal hippocampus (Quirion et al., 1983; Mansour et al., 1987).

Several lines of evidence have demonstrated that the ventral hippocampus may be more important than its dorsal portion for the expression of seizures and WDS in rats. First, autoradiographic studies have shown that $2-D G$ utilization during seizures induced by hippocampal kindling or kainic acid is higher in the ventral hippocampus (Lothman and Collins, 1981; Lothman et al., 1985). Second, it has been demonstrated by studies using hippocampal slices that potassium-induced bursting of $\mathrm{CA}_{3}$ pyramidal cells peaked approximately $1.5 \mathrm{~mm}$ from the tip of the ventral hippocampus and declined toward the dorsal end (Bragdon et al., 1986). Third, the abundance of ME and DYN in the ventral hippocampus is higher than those in the dorsal hippocampus (Kanamatsu et al., 1986). Fourth, colchicine lesions of ventral but not dorsal hippocampal dentate granule cells inhibited kainic acid-induced WDS (Grimes, Merritt, Tilson, and Hong, personal communication). Fifth, intracerebral injections of kainic acid to different brain regions have indicated that the ventral hippocampus is the most sensitive site in eliciting convulsions and WDS (Thai, Zhang, and Hong, personal communication). Since the present study shows that the ventral but not the dorsal hippocampus plays an important role in opioid-induced convulsions and WDS, the relatively higher concentration of endogenous opioids (Kanamatsu et al., 1986) and opioid receptors (Mansour et al., 1987) in the ventral hippocampus may contribute an important factor in the regional differences observed.

Opioid peptides have been demonstrated to inhibit neuronal firing in most areas of the brain; however, they increase the firing of hippocampal pyramidal cells (Nicoll et al., 1977; Zieglgansberger et al., 1979). It has been suggested that opioid peptides increase hippocampal pyramidal cell firing rates by inhibiting adjacent inhibitory interneurons such as the GABAergic neurons (Zieglgansberger et al., 1979; Siggins and Zieglgansberger, 1981). In the present study, opioids were injected into the stratum lacunosum-moleculare of Ammon's horn in the ventral hippocampus, which has been demonstrated to have high density of mu opioid receptors (Crain et al., 1986; Mansour et al., 1987). Moreover, this is also the region where enkephalincontaining perforant path fibers from entorhinal cortex (Gall et al., 1981; Fredens et al., 1984) and interneuronal GABA-containing fibers terminate (Gamrani et al., 1986; Sloviter and Nilaver, 1987). Thus, the injections of mu agonists to this region may reduce the degree of recurrent inhibition of the pyramidal cells, resulting in excitation and epileptiform activity originating in the ventral hippocampus. This seizure activity from the ventral hippocampus when radiated to the motor area of the brain may lead to the expression of WDS and convulsions.
The induction of WDS by mu agonists in this study appears to be associated with generalized convulsions since the inhibition of convulsions by $\beta$-FNA also inhibits WDS. This is in accordance with previous reports where WDS have been observed in rats with various experimentally induced seizures such as amygdala kindling (Squillace et al., 1980), cobalt epilepsy (Colasanti et al., 1975), or kainic acid-induced limbic seizures (Lanthorn and Isaacson, 1978). Hippocampal epileptiform discharges provoked by opioid peptides are accompanied by WDS (Frenk et al., 1978; Henriksen et al., 1978). In addition, hippocampal granule cell discharges have also been demonstrated to be necessary for the induction of this shaking behavior ( $\mathrm{Da}$ miano and Connor, 1984), suggesting that there is an association between WDS and hippocampal epileptiform discharges. However, bilateral colchicine lesions of ventral hippocampal granule cells inhibit PL017-induced WDS but potentiate the severity of convulsions (Lee et al., unpublished observations). This observation suggests that the ventral hippocampus may be an important site in eliciting both WDS and convulsions by mu agonists; however, the expression of these 2 behaviors does not appear to depend on a common underlying mechanism.

In summary, our findings clearly demonstrate that mu receptors in the ventral hippocampus are important for the expression of opioid-induced convulsions and WDS. In addition, the remarkable regional selectivity of the ventral hippocampus in association with the expression of convulsions and WDS induced by opioids and other chemical convulsants, such as kainic acid, underlines the necessity of studying this particular brain region in great details since previous findings on the hippocampus have focused on the dorsal hippocampus almost exclusively.

\section{References}

Blanchard, S. G., P. H. K. Lee, W. W. Pugh, J. S. Hong, and K. J. Chang (1987) Characterization of the binding of a morphine $(\mu)$ receptor specific ligand: Tyr-Pro-NMePhe-D-Pro- $\mathrm{NH}_{2},\left[{ }^{3} \mathrm{H}\right]-\mathrm{PL} 17$. Mol. Pharmacol. 31: 326-333.

Bragdon, A. C., D. M. Taylor, and W. A. Wilson (1986) Potassiuminduced epileptiform activity in area $\mathrm{CA}_{3}$ varies markedly along the septotemporal axis of the rat hippocampus. Brain Kes. 378: 169-173.

Cain, D. P., and M. E. Corcoran (1984) Intracerebral $\beta$-endorphin, Met-enkephalin and morphine: Kindling of seizures and handlinginduced potentiation of epileptiform effects. Life Sci. 34: 2525-2542.

Cain, D. P., and M. E. Corcoran (1985) Epileptiform effects of Metenkephalin, $\beta$-endorphin and morphine: Kindling of generalized seizures and potentiation of epileptiform effects by handling. Brain Res. 338: 327-336.

Chang, K., and P. Cuatrecasas (1979) Multiple opiate receptors. J. Biol. Chem. 254: 2610-2618.

Chang, K. J., E. T. Wei, A. Killian, and J. K. Chang (1983) Potent morphiceptin analogs: Structure activity relationships and morphinelike activities. J. Pharmacol. Exp. Ther. 227: 403-408.

Colasanti, B. K., J. E. Kosa, and C. R. Craig (1975) Appearance of wet-dog shakes behavior during cobalt experimental epilepsy in the rat and its suppression by reserpine. Psychopharmacologia (Berl.) 44: 33-36.

Cotton, R., M. G. Giles, L. Miller, J. S. Shaw, and D. Timms (1984) ICI-174,864: A highly selective antagonist for the opioid delta receptor. Eur. J. Pharmacol. 97: 331-332.

Cowan, A., E. B. Geller, and M. W. Adler (1979) Classification of opioids on the basis of change in seizure threshold in rats. Science 206: 465-467.

Crain, B. J., K. J. Chang, and J. O. McNamara (1986) Quantitative autoradiographic analysis of $\mathrm{mu}$ and delta opioid binding sites in the rat hippocampal formation. J. Comp. Neurol. 246: 170-180.

Damiano, B. P., and J. D. Connor (1984) Hippocampal mediation of shaking behavior induced by electrical stimulation of the perforant path in the rat. Brain Res. 308: 383-386.

Dzoljic, M. R., and A. L. Poel-Heisterkamp (1982) Delta opiate re- 
ceptors are involved in cndopioid-induced myoclonic contractions. Brain Res. Bull. 8: 1-6.

Fredens, K., K. Stengaard-Peterson, and L. I. Larsson (1984) Localization of enkephalin and cholecystokinin immunoreactivities in the perforant path terminal fields of the rat hippocampal formation. Brain Res. 304: 255-263.

Frenk, H. (1983) Pro- and anticonvulsant actions of morphine and the endogenous opioids: Involvement and interactions of multiple opiate and non-opiate systems. Brain Res. Rev. 6: 197-210.

Frenk, H., G. Urca, and J. C. Liebeskind (1978) Epileptic properties of leucine- and methionine-enkephalin: Comparison with morphine and reversibility by naloxone. Brain Res. 147: 327-337.

Gall, C., N. Brecha, H. J. Karten, and K. J. Chang (1981) Localization of enkephalin-like immunoreactivity to identified axonal and neuronal populations of the rat hippocampus. J. Comp. Neurol. 198: $335-350$.

Gamrani, H., B. Onteniente, P. Seguela, M. Geffard, and A. Calas (1986) Gamma-aminobutyric acid immunoreactivity in the rat hippocampus. A light and electron microscopic study with anti-GABA antibodies. Brain Res. 364: 30-38.

Haffmans, J., and M. R. Dzoljic (1983) Differential epileptogenic potentials of selective $\mu$ and $\delta$ opiate receptor agonists. J. Neural Transmission 57: 1-11.

Haffmans, J., Y. Blankwater, O. E. Uponmwan, F. J. Zijlstra, J. E. Vincent, W. Hespe, and M. R. Dzoljic (1983) Correlation between the distribution of ${ }^{3} \mathrm{H}$-labelled enkephalin in rat brain and the anatomical regions involved in the enkephalin-induced seizures. Neuropharmacology 22: 1021-1028.

Haffmans, J., E. R. de Kloet, and M. R. Dzoljic (1984) Metabolic rate in different rat brain areas during seizures induced by a specific delta opiate receptor agonist. Brain Res. 302: 111-115.

Handa, B. K., A. C. Lane, J. A. H. Lord, B. A. Morgan, M. J. Rance, and C. F. C. Smith (1981) Analogues of beta-LPH L1-64 possessing selective agonist activity at mu-opiate receptors. Eur. J. Pharmacol. 70: $531-541$.

Henriksen, S. J., F. E. Bloom, F. McCoy, N. Ling, and R. Guillemin (1978) Beta-endorphin induces nonconvulsive limbic seizures. Proc. Natl. Acad. Sci. USA 75: 5221-5225.

Holaday, J. W., and F. C. Tortella (1984) Multiple opioid receptors: Physiological functions of mu and delta binding sites in vivo. In Central and Peripheral Endorphins: Basic and Clinical Aspects, E. E. Muller and A. R. Genazzani, eds., pp. 237-250, Raven, New York.

James, I. F., and A. Goldstein (1984) Site-directed alkylation of multiple opioid receptors. I. Binding selectivity. Mol. Pharmacol. 25:337342.

Kanamatsu, T., J. Obie, L. Grimes, J. McGinty, K. Yoshikawa, S. Sabol, and J. S. Hong (1986) Kainic acid alters the metabolism of $\mathrm{Met}^{5}-$ enkephalin and the level of dynorphin $\mathrm{A}$ in the rat hippocampus. $\mathrm{J}$. Neurosci. 6: 3094-3102.

Lanthorn, T., and R. L. Isaacson (1978) Studies of kainate-induced wet-dog shakes in the rat. Life Sci. 22: 171-178.

Lee, P. H. K., J. Obie, P. Hudson, and J. S. Hong (1987) Intrahippocampal injection of opiate peptides produces wet dog shakes, convulsions and changes in the levels of amino acids. Soc. Neurosci. Abstr. 13: 1307.

Lee, P. H. K., J. Obie, and J. S. Hong (1988) Intrahippocampal injections of a specific mu-receptor ligand PL017 produce generalized convulsions in rats. Brain Res. 441: 381-385.

Lord, J. A. H., A. A. Waterfield, J. Hughes, and H. W. Kosterlitz (1977) Endogenous opioid peptides: Multiple agonists and receptors. Nature 267: 495-499.

Lothman, E. W., and R. C. Collins (1981) Kainic acid induced limbic seizures: Metabolic, behavioral, electroencephalographic and neuropathological correlates. Brain Res. 218: 299-318.

Lothman, E. W., J. M. Hatlelid, and C. F. Zorumski (1985) Functional mapping of limbic seizures originating in the hippocampus: A combined 2-deoxyglucose and electrophysiologic study. Brain Res. 360: 92-100.

Mansour, A., H. Khachaturian, M. E. Lewis, H. Akil, and S. J. Watson (1987) Autoradiographic differentiation of mu, delta and kappa opioid receptors in the rat forebrain and midbrain. J. Neurosci. 7: 24452464.
Martin, W. R. (1967) Opioid antagonists. Pharmacol. Rev. 19: 464 521.

Martin, W. R., C. G. Eades, J. A. Thompson, R. E. Huppler, and P. E. Gilbert (1976) The effect of morphine- and nalorphine-like drugs in the nondependent and morphine-dependent chronic spinal dog. J. Pharmacol. Exp. Ther. 197: 517-523.

Mosberg, H. I., R. Hurst, V. J. Hruby, K. Gee, H. I. Yamamura, J. J. Galligan, and T. F. Burks (1983) Bis-penicillamine enkephalins show pronounced delta opioid receptor selectivity. Proc. Natl. Acad. Sci. USA 80: 6871-6874.

Nicoll, R. A., G. R. Siggins, N. Ling, F. E. Bloom, and R. Guillemin (1977) Neuronal actions of endorphins and enkephalins among brain regions: A comparative microiontophoretic study. Proc. Natl. Acad. Sci. USA 74: 2584-2588.

Paxinos, G., and C. Watson (1982) The Rat Brain in Stereotaxic Coordinates, Academic, Sydney.

Quirion, R., J. M. Zajac, J. L. Morgat, and B. P. Roques (1983) Autoradiographic distribution of mu and delia receplors in rat brain using highly selective ligands. Life Sci. (Suppl. 1) 33: 227-230.

Siggins, G. R., and W. Zieglgansberger (1981) Morphine and opioid peptides reduce inhibitory synaptic potentials in hippocampal pyramidal cells in vitro without alteration of membrane potential. Proc. Natl. Acad. Sci. USA 78: 5235-5239.

Sloviter, R. S., and G. Nilaver (1987) Immunocytochemical localization of GABA-, cholecystokinin-, vasoactive intestinal polypeptide-, and somatostatin-like immunoreactivity in the area dentata and hippocampus of the rat. J. Comp. Neurol. 256: 42-60.

Snead, O.C. (1986) Opiate induced seizures: A study of $\mu$ and $\delta$ specific mechanisms. Exp. Neurol. 93: 348-358.

Snead, O. C., and L. J. Bearden (1980) Anticonvulsants specific for petit mal antagonize epileptogenic effect of leucine-enkephalin. Science 210: 1031-1033.

Squillace, K. M., R. M. Post, and A. Pert (1980) Development of wetdog shakes during amygdala kindling in the rat. Exp. Neurol. 70:487497.

Takemori, A. E., D. L. Larson, and P. S. Portoghese (1981) The irreversible narcotic antagonistic and reversible agonistic properties of the fumaramate ester methyl derivative of naltrexone. Eur. J. Pharmacol. 70: 445-451.

Tanaka, T., Y. Hamasaki, H. Takeshitak, R. Kawahara, and H. Hazama (1986) Chemical kindling with Met-enkephalin and changes of brain opioid delta-receptor sensitivity after electrical kindling. Epilepsia 27: 596.

Tang, A. H., and R. J. Collins (1985) Behavioral effects of a novel kappa opioid analgesic, U-50,488, in rats and rhesus monkeys. Psychopharmacology 85: 309-314.

Tortella, F. C., J. E. Moreton, and N. Khazan (1979) Electroencephalographic and behavioral tolerance to and across-tolerance between $D$-Ala ${ }^{2}$-methionine-enkephalinamide and morphine in the rat. $\mathbf{J}$. Pharmacol. Exp. Ther. 210: 174-179.

Tortella, F. C., L. Robles, H. I. Mosberg, and J. W. Holaday (1984) Electroencephalographic assessment of the role of $\delta$ receptors in opioid peptide-induced seizures. Neuropeptides 5: 213-216.

Tortella, F. C., L. Robles, and H. I. Mosberg (1987) Evidence for mu opioid receptor mediation of enkephalin-induced electroencephalographic seizures. J. Pharmacol. Exp. Ther. 240: 571-577.

Urca, G., H. Frenk, J. C. Liebeskind, and A. N. Taylor (1977) Morphine and enkephalin: Analgesic and epileptic properties. Science 197: 83-86.

Von Voightlander, P. F., R. A. Lahti, and J. H. Ludens (1983) U-50,488: A selective and structurally novel non-mu (kappa) opioid agonist. J. Pharmacol. Exp. Ther. 224: 7-12.

Zajac, J. M., G. Gacel, F. Petit, P. Dodey, and B. P. Roques (1983) Deltakephalin, Tyr-D-Tyr-Gly-Phe-Leu-Thr: A new highly potent and fully specific agonist for opiate delta receptors. Biochem. Biophys. Res. Commun. 111: 390-397.

Zieglgansberger, W., E. D. French, G. R. Siggins, and F. E. Bloom (1979) Opioid peptides may excite hippocampal pyramidal neurons by inhibiting adjacent inhibitory interneurons. Science 205: 415-416. 